ELORE (ISSN 1456-3010), vol. 19 - 2/2012.

Julkaisija: Suomen Kansantietouden Tutkijain Seura ry.

[http://www.elore.fi/arkisto/2_12/saarikoski.pdf]

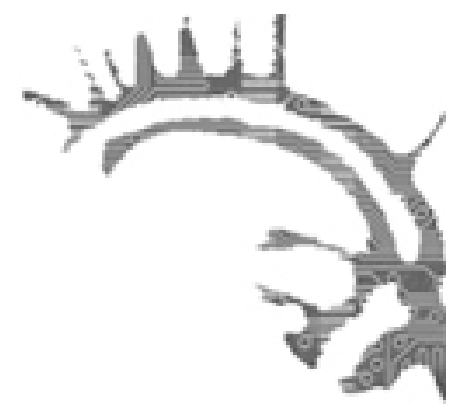

\title{
Ajankohtaista
}

\section{SUOMENKIELISTEN TIEDEKIRJOJEN KOHTALOISTA}

\author{
Helena Saarikoski
}

Puheenvuoro Suomen Kansantietouden Tutkijain Seuran VI Kevätkoulussa 16.5.2012

Keskustelunalustukseni tässä tieteellisen julkaisemisen työpajassa käsittelee suomenkielistä tiedekirjaa. Puhun lähinnä tutkijan, kirjantekijän ja tietokirjailijan ja nyt vähän myös kustantajan kokemuksesta.

\section{TIEDEKIRJAN GENRE TIETOKIRJALLISUUDESSA}

Olen pyrkinyt kaikissa kirjoissani kehittämään tiedekirjan genreä siihen suuntaan, että tutkimuksen esitys voisi olla samalla yleistajuinen ja yleisesti kiinnostava kirja. Nyt jotkut sanovat, että tutkimuskirjoittaminen ja populaari kirjoittaminen ovat kaksi aivan eri asiaa, ja tutkijan on ensin julkaistava tutkimuksensa tutkimuksena ja sen jälkeen tulee erikseen popularisointi. Olen samaa mieltä siitä, että tiedekirja ja tietokirja ovat kaksi eri asiaa. Mutta se ei estä yrittämästä omia tietokirjan hyviä puolia myös tiedekirjalle. Harvalla tutkijalla riittää aikaa, voimia ja rahoitusta alkaa tutkimuksen julkaisemisen jälkeen kirjoittaa samasta aiheesta erillistä populaaria kirjaa.

Suomenkielisen tiedekirjan ensimmäinen kohtalonkysymys on tutkimuksen esittäminen selkeässä, yleisesti ymmärrettävässä muodossa, sellaisena, että se voi kiinnostaa 
muitakin kuin toisia saman alan tutkijoita.

Lähtökohtani on, että silloin kun tutkitaan suomalaista kulttuuria suomalaisen yhteiskunnan varoin, tutkimuksen tulokset on tilitettävä suomalaisen yleisön käyttöön. Tutkimusetiikka vaatii sitä. Kulttuurientutkimuksen pienten tieteenalojen eloonjäämisstrategia vaatii sitä - jos ajatellaan, että yhteiskunta kustantaa tutkimusta, koska se pitää tutkimusta itselleen arvokkaana toimintana. Muuhun ei ole aihetta: tutkimus ei ole etuoikeutettu professio, jota yhteiskunta ylläpitäisi puhtaasta halustaan sukia akateemisen eliitin sivistyneitä ja aina niin ylen miellyttäviä jäseniä. Voisi jopa sanoa, että ihmistieteellisen tutkimuksen tai ainakin kansankulttuurien tutkimuksen tulee kaikin voimin pyristellä irti tällaisen etuoikeuden aaveista.

Usein sanotaan, että tiedekirjan ja tietokirjan raja on veteen piirretty viiva, mistä näyttäisi ikään kuin seuraavan, että tiedekirjan tekijä voi helposti tullakin vahingossa tehneeksi tietokirjan tai päinvastoin. Tiedekirjalla ja tietokirjalla on kuitenkin selvä ero: tietokirja ei saa sisältää mutta tiedekirjan täytyy sisältää uutta tutkimusta, tiedeyhteisössä vielä tieteelliseksi hyväksymätöntä tietoa. Julkaiseminen tietosarjassa edellyttää, että tieto on jo punnittua ja hyväksyttyä, luotettavaa tietoa, eikä vasta tuoda esille tiedeyhteisön arvioitavaksi, onko se hyväksyttävää.

Niin pienellä alalla kuin folkloristiikka myös tiedekirja on kuitenkin syytä kirjoittaa suhteellisen yleistajuisesti, vaikka ei edes ajateltaisi suurta suomalaista yleisöä tavoiteltuna lukijakuntana. Kirjan vaatima työmäärä jo edellyttää sitä, että joidenkin muidenkin kuin vain niiden viiden tai kymmenen suomalaisen folkloristin täytyy voida ymmärtää tutkimusta, jotka ovat tutkimusaiheesta niin kiinnostuneita, että lukevat kirjan. Tutkimuksen metodologisen läpinäkyvyyden, koeteltavuuden ja luotettavuuden vaatimukset edellyttävät sitä, että tutkija pyrkii kaikin keinoin tekemään tieteestään kielellisesti hyvän esityksen: yleisesti ja yhtäläisesti ymmärrettävän tekstin.

\section{NELJÄ KIRJAA, NELJÄ KOHTALOA}

Olen kirjoittanut neljä kirjaa, jotka lähtökohdiltaan ovat tiedekirjoja siinä mielessä, että niissä käsitellään alkuperäisaineistoa ja luodaan uusia, ensimmäistä kertaa niissä julkaistavia tulkintoja. Kaksi näistä kirjoista on ilmestynyt tiedekustantajalta eli Suomalaisen Kirjallisuuden Seuran julkaisemina ja kaksi kaupallisilta kustantajilta.

Kuten Tieteellisten seurojen valtuuskunnan äskettäin julkistama Julkaisufoorumi (2011) antaa ymmärtää, kirjojen kohteluun ja kohtaloihin on selvästi vaikuttanut se, jos ne ovat ilmestyneet kaupallisten kustantajien kustantamina.

Ensimmäinen näistä, Mistä on huonot tytöt tehty? oli kirja, jonka kustantaja itse tarjoutui julkaisemaan nähtyään jonkin artikkelini tutkimusaiheesta. Aiheessa oli siis kaupallista potentiaalia ja tekijään saattoi ilmeisesti luottaa kirjoittajana. Kirja ilmestyi Tammelta naistenpäivänä 2001. Kirja sai hyvin paljon huomiota, menekkiä ja lukijoita, ja se hyväksyttiin myös virallisessa menettelyssä tieteelliseksi tutkimukseksi, kun se oli väitöskirjani ohella toinen minut dosentuuriin pätevöittäneistä teoksista, ja sitä on käytetty paljon kurssikirjana yliopistoissa ja käytetään jopa edelleen. 
Kuitenkin olen kirjan nyt jo yhdentoista vuoden olemassaolon aikana huomannut, että suurelta osalta tiedeyhteisöä on mennyt ohi se, että kirja on tutkimus, eikä esimerkiksi jokin feministinen pamfletti. Tiedekirjan tekijän kannalta tilanne on hyvin ristiriitainen, jos kirjan saama suuri huomio johtaa sen sulkemiseen pois vakavasti otettavasta tiedekirjallisuudesta. Kaiken kirjallisuuden tarkoitus on tavoittaa lukijoita, ja tutkimuksen paljon kuulutetun yhteiskuntarelevanssin kannalta on myös välttämätöntä, että tutkimus voi tavoittaa laajan yleisön ilman, että se sen takia katsotaan joksikin muuksi kuin tutkimukseksi.

Yksi syy tähän kirjan jonkinasteiseen ohitukseen on oma lapsukseni, joka olisi ollut helppo välttää, jos olisin arvannut, että näin voi käydä. Kirjalla ei ollut "asiallista" alanimekettä myyvän päänimekkeen lisäksi. Myyvä päänimeke on tietenkin must silloin, kun kirjan julkaisee kaupallinen kustantaja. Nyt kun Kulttuuriosuuskunta Partuuna julkaisee tämän kirjan uudestaan saataville, olen antanut kirjalle asianmukaisen tieteellisen alanimekkeen "Tutkimus huora-sanan käytöstä ja tyttöjen kokemasta kiusaamisesta" (Saarikoski 2012a).

Kun tein toista painosta julkaisukuntoon, oli hauska huomata, että tutkimus ei ole kymmenessä, kahdessatoista vuodessa pahemmin vanhentunut. Se on tietenkin joissain suhteissa oman aikansa kuva, mutta puolustaa kyllä edelleen paikkaansa. On erityistä kulttuurientutkimukselle, verrattuna joihinkin mediaseksikkäämpiin tieteenaloihin, että tutkimuskohde muuttuu hitaasti ja kunnolliset kuvaukset ja perustellut tulkinnatkaan eivät vanhene hetkessä. Kun laajan tutkimuksen ja kokonaisen tiedekirjan tekeminen kestää vähimmillään vuosia, jopa kymmeniä vuosia, silkka työekonomia edellyttää, että työn tulokset kestävät aikaa. Se, että tieteenalalla suositaan kokonaisesityksiä, monografioita ja kirjamuotoista julkaisemista, ei ole postmodernissa tarpeettomaksi käynyttä perinteen painolastia, vaan tieteen sisällöllinen kysymys, jolla on myös vaikutuksensa tutkimuksen mahdollistaviin työehtoihin.

\section{ONKO VÄITÖSKIRJA KIRJA, ONKO VÄITÖSKIRJALLA TEKIJÄ?}

Kaupallinen kustantaja ei pysty kuin joissain aivan poikkeustapauksissa pitämään kirjaa saatavilla likikään näin kauan, yli kymmentä vuotta. Tällä kokemuksella tuntuu hienolta, että väitöskirjani (1994) on edelleen myynnissä SKS:n kirjakaupassa kahdeksantoista vuotta ilmestymisen jälkeen. Nähtäväksi jää, onko nyt pdf-tiedostoina yliopiston Ethesistietokannassa julkaistavilla väitöskirjoilla yhtä pitkä elinkaari edessään.

Kummassakaan tapauksessa, antaessani aikoinaan väitöskirjani SKS:n julkaistavaksi tai kun nykyinen väittelijä antaa väitöskirjansa yliopiston julkaistavaksi sähköisessä tietokannassa, kirjantekijä ei saa tekijänoikeuslain turvaamaa korvausta teoksen julkaisemisesta ja jakelusta. Tiedekustantajat saattavat edelleen odottaa saavansa muutkin kirjat kuin väitöskirjat myydäkseen ilman tekijälle kuuluvaa korvausta. SKS:lta sain sentään tekijänkappaleiden lisäksi yliopiston edellyttämät jakelukappaleet (silloin 160 kappaletta), kun nykyinen väittelijä joutuu kustantamaan tarvittavat painetut kirjat itse.

Kun väitöskirjat muodostavat leijonanosan tutkimuksen volyymista, ainakin folkloris- 
tiikan kaltaisella alalla jossa tutkijan työpaikkoja on vähän mutta innostuneita opiskelijoita siihen verrattuna paljon, ja kun valmistuneet väitöskirjat muodostavat leijonanosan myös yliopiston rahoitukseksi vaihdettavasta tuloksesta, on sietämätöntä riistoa, että työtä ei korvata tekijälle millään tavalla (ks. myös Saarikoski 2012b). Ei tutkija eikä kirjantekijä elä pyhällä hengellä eikä artistilla ole, millä maksaa. Suomen Akatemian ajama julkaisupolitiikka, jonka mukaan yliopiston opiskelijoiden ja tutkijoiden on annettava työnsä tulokset korvauksetta yliopistolle, ja siihen liittyvä alamme tiedekustantajan politiikka, ettei väitöskirjoja enää julkaista kirjoina, ovat syvässä ristiriidassa tekijäjärjestöjen politiikkatavoitteiden kanssa (Suomen Tietokirjailijat ry:n politiikkatavoitteet).

Ilmeisesti yliopistoonkin tutkijoidensa töiden julkaisijana pätee kirjailija Hannu Niklanderin näkemys (Heiskanen 2001): "Kustantajan ja kirjailijan kesken vallitsee sovittamaton pääoman ja työn välinen ristiriita. Voittoa pitää tulla." On kohtuutonta ja kestämätöntä, ettei voittoa jaeta tekijöilleen lainkaan.

\section{LIIAN PAHA KIRJAKSI?}

Myös toinen kaupallisella kustantajalla ilmestynyt kirjani Kateus, juoru, kiusaaminen esseitä henkisestä yhteisöväkivallasta (2006) on myyty loppuun muutamassa vuodessa. Kirja sai sekä mediahuomiota että paljon koskettavaa lukijapalautetta, jonka ansiosta olen voinut tuntea tehneeni todella tärkeän kirjan. Lähtökohtaisesti riskibisnes, äärimmäisen vaikea aihe kirjoittaa kirjaksi ja luotaantyöntävä myydä lukijoille, työpaikkakiusaaminen kirjoittajan omana kokemuksena, kääntyi, ilmeisesti tämän tärkeyden voimalla, tekijän hämmästykseksi ja kustantajan iloksi, "pienimuotoiseksi hitiksi".

Mutta tämän kirjan kohdalla ongelmaksi on muodostunut sen sijoittaminen genreen eli hyväksyminen tiedekirjaksi. Olen yrittänyt kirjassa tuottaa etnografisessa metodologiakirjallisuudessa kuulutettua kokeilevaa kirjoittamista ja sitä kautta kehittää etnografian esittämisen metodologisia valmiuksia. Kirjan nimekkeessä sana esseitä eli 'kokeita' tarkoittaa tätä, ei sitä, että pyytelisin anteeksi "pelkkien esseiden" julkaisemista, joten kirjasta ei tarvitse muuta tietääkään, kuten eräässä yliopistotyöpaikan haussa tulkittiin.

Ainoa tiedeyhteisön arvovaltainen palaute tästä kirjasta on tullut professorihaussa, jossa kirjassa kuvattujen tapahtumien aikana tapahtumapaikan tiedekunnan dekaanina toiminut asiantuntija totesi julkisessa lausunnossaan, että kirja on pikemminkin tietokirja kuin tutkimusta. Autoetnografialle on ominaista kirjoittamisen lajina ja metodologiana, että se juuri käy koko ajan tieteellisyyden rajaa. Lausunto perustuu kuitenkin värinkäsitykseen, että tietokirja olisi jotenkin huonommaksi luokiteltavan tutkimuksen kaatoluokka. Jos kirja ei ole hyväksyttävissä tieteeksi eli uutta tietoa sisältäväksi, vaikka siinä käsitellään omaa alkuperäisaineistoa uusin tulkinnoin, se ei ole todellakaan tietokirjallisuutta. Vanhaa tietoa se ei ole ja uudeksi tiedoksi sitä ei hyväksytä. Siinä tapauksessa kirja on luokiteltava kaunokirjallisuudeksi. Se on epäilemättä huonoa kaunokirjallisuutta ja tässä genreluokituksessa tappion kärsii mielestäni sekä tiede että taide. Mutta viranhaun asiantuntijan tieteellistä pätevyyttä ei ole lupa kyseenalaistaa, joten tähän tappioon on tyytyminen. 
Helena Saarikoski: Suomenkielisten tiedekirjojen kohtaloista

\section{LUKIJAT OVAT TIEDEKIRJANKIN KOHTALONKYSYMYS}

Näiden kahden kaupallisella kustantajalla ilmestyneen kirjan kohtaloista varmaankin on johtunut se, että uusimman kirjani, vuonna 2009 SKS:n Tiede-sarjassa ilmestyneen kirjan Nuoren naisellisuuden koreografoita. Spice Girlsin fanit tyttöyden tekijöinä, olen halunnut virittää varmasti tieteelliseksi ja varmistaa tiedekirjaksi luokittelemisen saattamalla kirjan SKS:n refereearviointiin (vaikka tämä merkitsi vuoden viivästymistä kirjan ilmestymisaikataulussa). Jo refereearviot ennakoivat kirjan suorastaan loistavaa tieteellistä arvostelumenestystä kymmenessä kulttuurintutkimuksen ja lähialojen lehdessä. Tieteellinen tunnustus kirjalle ei jättänyt toivomisen varaa.

Mutta vastapainoksi kirjaa ei ole myyty, nyt kahdessa ja puolessa vuodessa ilmestymisestä, kuin murto-osa siitä, mitä kumpaakin aiempaa kirjaani samassa ajassa. Sitä on myyty vain kymmeniä, ei satoja kappaleita, huolimatta aiheen mahdollisesti hyvinkin laajasta kiinnostavuudesta ja vaikken ole kirjoittajana suinkaan luopunut tyyliharjoituksestani, pyrkimyksestä hyvään ja yleisesti ymmärrettävään tekstiin.

En ole kirjantekijänä enkä tutkijana valmis ostamaan kuvitteellista "meriittiä", hienoja uusia rivejä tieteelliseen julkaisuluettelooni ja hienoja tulospisteitä yliopiston tilille sillä, että kirja jää käytännössä ilman lukijoita. Lukijat, yleinen ymmärrettävyys ja kiinnostavuus, yhteiskuntarelevanssi, se, että tiedekirja myy ja ottaa paikkansa yleisessä tietoisuudessa, on myös suomenkielisen tiedekirjan kohtalonkysymys. Jos tiedekustantajille on annettu monopoli julkaista tiedeyhteisössä tieteeksi hyväksyttäviä kirjoja, kohtalon avaimet on ilmeisesti annettu tiedekustantajien markkinointiosastojen käsiin.

\section{KiRJALLisuUS}

HEISKANEN, RIITTA 2001: Perintötaakka kasvatti runoilijaksi. Helsingin Sanomat 16.3.2001, Ihmiset.

Julkaisufoorumi. Tieteellisten seurain valtuuskunta (2011) [online]. < http://www.tsv. fi/julkaisufoorumi/ > [19.9.2012.]

SAARIKOSKI, HELENA 1994: Kouluajan kivoin päivä. Folkloristinen tutkimus penkinpainajaisperinteestä. Suomalaisen Kirjallisuuden Seuran Toimituksia 617. Helsinki: SKS.

SAARIKOSKI, HELENA 2006: Kateus, juoru, kiusaaminen - esseitä henkisestä yhteisöväkivallasta. Helsinki: Nemo.

SAARIKOSKI, HELENA 2009: Nuoren naisellisuuden koreografioita. Spice Girlsin fanit tyttöyden tekijöinä. Suomalaisen Kirjallisuuden Seuran Toimituksia 1230, Tiede. Helsinki: SKS.

SAARIKOSKI, HELENA 2012a: Mistä on huonot tytöt tehty? Tutkimus huora-sanan käytöstä ja tyttöjen kokemasta kiusaamisesta. 2. korjattu painos. Helsinki: Partuuna. (1. painos Helsinki: Tammi 2001.)

SAARIKOSKI, HELENA 2012b: Miksi minä olen lähtenyt osuuskuntaan? Ensimmäi- 
Helena Saarikoski: Suomenkielisten tiedekirjojen kohtaloista

nen lokilukema 14. maaliskuuta 2012 [online] < http://www.partuuna.fi/arkisto > [19.9.2012.]

Suomen Tietokirjailijat ry:n politiikkatavoitteet [online] < http://www.suomentietokirjailijat.fi/?x18668=100637 > [19.9.2012. $]$

Filosofian tohtori Helena Saarikoski on folkloristiikan ja naistutkimuksen dosentti Helsingin yliopistossa, vapaa tutkija ja tietokirjailija sekä Kulttuuriosuuskunta Partuunan toimitusjohtaja. 